\title{
The Effect and Role of Political Dialogue in Relations between Countries in the Region (with Emphasis on Iran and Tajikistan Model: SCO)
}

\author{
Mahmoud Shahbandi ${ }^{1}$ \\ ${ }^{1}$ Research Center, Tehran University of International Studies ( $\mathrm{PhD}$ in Political Science of the Russian \\ Federation) \\ Correspondence: Mahmoud Shahbandi.E-mail: shahbandi@ut.ac.ir \& shahbandim@yahoo.com
}

Received: August 16, 2016

doi:10.5539/ass.v13n6p20
Accepted: December 27, $2016 \quad$ Online Published: May 31, 2017

URL: https://doi.org/10.5539/ass.v13n6p20

\begin{abstract}
Within review of Iran and Tajikistan and conducted studies, one should take into account some considerations due to geopolitical position viewpoint. In this process, Tajikistan can be considered one of the strong and old cultures and one of the greatest regional civilizations, considering the type of change in its political atmosphere can develop its relation with Iran. Therefore, here. The dialogue is not merely under consideration, rather, the relation within the dialogue is considered at regional level. Reviewing components contributing in relation and political dialogue, objective and means of political dialogue, system analysis and theoretic knowledge and methodology based on political talk and their features in a regional context should be discussed to evaluate the circumstances of Iran and Tajikistan within social and political context for encouraging political dialogue through Shanghai Cooperation Organization (SCO) as a regional political tool.
\end{abstract}

Keywords: Political dialogue, Iran and Tajikistan, Regional relations, SCO

\section{Introduction}

Soviet Union collapse, now not very old historical event, at that time, in addition to bringing the world into a new era, significantly suggested the lack of mutual understanding in the political dialogueue between America and the Soviet Union. And it was an obvious experience for other countries implying that use of dialogueue between countries could strengthen their relationships. Over the past few decades, people believed that a discussion on region countries is an old debate, But with the recent conflicts (April 2014) in the breakaway Ukrainian, from Russian Federation, who itself was one of the original members of the Russian Federation, and asked for the annexation of the country to the European Union indicates perseverance of this subject. Therefore, fostering the dialogue (Шахрамния С. 2007) as a thesis, that serves as liberating solution for the region of conflict and war can be discussed again (Махмадов. Душанбе, 2010). The collapse of the Soviet Union provided good conditions in different areas of culture, (Сажина В.И М, 2002) for policy makers in these countries, especially Tajikistan internationally and in particular with countries with same language, like Iran. So they would be able to strengthen the dialogueue (Махмадов. Душанбе, 2010; 2011) in the political and cultural contexts more than ever. Iran is a country that historically can fill the Tajik vacuum identity, regarding the culture, and set the stage for strengthening the relationship between the two countries. Although before and after Imam Ali Rahman coming to power in 2014 election (farsi-news.org), there have been some suggestions for mutual political dialogue between two countries, however, still this is Iran that can act as a consistent and compatible cultural base for Tajikistan in the context of strengthening national identity of Tajiks through political dialogue against Russian, Turkic and Uzbek cultural storm. Tajikistan can be strengthened political and cultural dialogueue between itself and Iran, to reduce or prevent the foreign invasion. Culture is so important, "Huntington" predicts that a war between civilizations (cultures) as the most global conflicts, meanwhile, ideological conflicts and other forms of conflict will be added. Hence, the need to strengthen the relationship between the regional countries, especially Tajikistan and Iran, on elements such as culture, language, and communication between the states and the significant presence in international organizations, the strengthening of political dialogueue (М. Хосейн Иран, 3 мая 2002) are emphasized. 


\section{Elements Involved in the Political Dialogueue}

Elements of society, such as, "culture", "communication", "dialogue", "attitude", with a clear understanding of the political dialogueue as a mechanism for exploiting social and political phenomena in society are considered. Indeed, political dialogueue is manifested in various forms and is not relied only on a unique action, but, actually, it lies in "everyday life, and in heart of realities". Accordingly, mastering the art of negotiation is highly important in other words, it calls for revisions in morale, talk and action. However, one may use "operational needs", particularly in political context.

Political dialogueue is a social phenomenon or a process which deals with social, economic, psychological and political issues. Political dialogueue and its features for being studied in a specific science calls for the use of various methods of political science, philosophy, psychology and other sciences, and integrating them successfully leads to solve problems.

Over past two or three decades, a kind of science, known as "self-dialogueue" has been developed on which not only cultural philosophers, but also sociologists and political scientists, and even representatives of the natural sciences discussed. In political science, this process is reflected at the different models of democracy that focuses on their relational nature.

Therefore, the review process of Iran-Tajikistan relation study derived from research, because of the kind of viewing from geopolitical standpoint, two countries calls for special attention. In this process, Tajikistan, considering the type of development of the current political atmosphere, with regard to commonalities with Iran, as an ancient culture, stronger, and one of the largest regional and local cultures should be addressed too. Therefore, the analysis of political dialogueue in social and cultural developments in Iran and the Republic of Tajikistan needs long-term regional and global forecasts, since the analysis of the performance of some countries depends on the relevance of the "behavior" (such as the United States to Iran), and this urges to study the influence of Russian Federation,

And this subject should not be excluded within study. Thus for scientific and theoretical study, one should describe the role of government in dynamism of relation between two states, namely Iran and Tajikistan. One should establish the position of political dialogue within this relation. One should in general understand the manner in which interest of both states can be satisfied. From other part, within all level of relation, the matter of dialogue is of high importance. In political science researches, one can draw on new technics and tools for qualitative analysis of political dialogue.

However, the type of relation determined by the study subject is of high importance. From one side, one should underline the importance of political dialogue as a mechanism for settling the social political problems. From other side, for having a comprehensive analysis, a complicated process of political dialogue within Iran performance is under consideration. Consequently, one should consider the complicated issues regarding changes in political status in central Asia as a geopolitical region as well is in Iran and Tajikistan which is a determining issue in this paper. Another important problem is the degree of complexity of study theme. Some political problems are featured by dynamism of international relations which should be addressed and aimed by researchers of political sciences. By studying the literature review and question of study, one can shed light on the degree of complexity of the subject and thus, one can understand the status of political dialogue in Iran politics. Today (2012), in Iran politics contexts, there is almost no study addressing the political dialogue, and if any, are not elaborated in a proper manner, yet this theme is highly importance in fostering international relations. In other word, this paper is sort of suggestion and provides a new perspective in new political processes. In this study, our main basis for study is the role of political dialogue within Iran-Tajikistan relations and basically some objectives should be considered.

a. The purpose of this study - given the internal situation and foreign policy dialogue in Iran and Tajikistan, emphasis is on strengthening the political dialogue in the region, particularly neighboring countries, especially Tajikistan and Iran.

b. Subject - the dialogue, as a form of interaction, policies and procedures, in the process of political dialogue.

c. The purpose of the research - identifying the characteristics of the political dialogue, relations between countries, particularly in Central Asia, and the Republic of Tajikistan.

To achieve this approach requires the following tasks appears:

1- As a result of analysis of system identification theory and methodology, based on policy dialogue and its features; 
2- Analyze the political dialogue as a form of discourse, culture, and its characteristics, the system of regional cooperation organizations, sample: Shanghai;

\section{Dialogue in Some Contemporary Theories}

Political dialogue as a mechanism for resolving political issues plays a role in contemporary political thought in varying degrees is emphasized on. (М. Хосейн Иран, 3 мая 2002; С. С. Хакиката.) Тегеран1991). In these works (Iranian and non-Iranian) different methods expressed concern about the quality, focus and ultimate objective of the dialogue are based on religious beliefs, morals and goals are. (Сажина В.И М, 2002) Intuitively, certain aspects of the theory of dialogue among civilizations, as a whole have in general addressed clear moment analysis aiming to cooperation with other countries. For authors who have expressed positive views on political dialogue, in the context of globalization, one can mention Late-Q. Time, t. Friedman, named (Beyer, Peter. New York, 1999). And their Iranian counterparts, with the understanding that (www.irtt.ir..) They believe in the political dialogueue, as a phenomenon is irreversible that leads to the development of science and technology with its self-adjustment feature. Some experts believe that Third World countries can significantly benefit by political dialogueue, to adapt to new conditions and to acquire global development. The political dialogueue in the modern political system in Iran can be used (Шахрамния C. 2007). Therefore, the problems, such as the concept and the nature of political dialogueue, particularly globalization, democracy and democratic institutions in the context of globalization, can be addressed and provide guidance for development principles, and democratic institutions in Iran. But these authors, at least in their individual opinions, have examined and described in terms of dialogueue, and noted that the dialogue failed to be used as necessary, or in some aspects of the formation of the concept of dialogueue, or aspects of history, culture and humanities, it seems to be limited. Considering the contribution of these philosophers and scientists, in this study, about dialogueue and related phenomena, it should be noted that the political dialogueue, in the present study, social, cultural and regional affairs of Iran and the Republic of Tajikistan, has been considered. Based on a specific set, researchers such as Jnkvsky, Mvlchanv, Prskvryn, Gvbaglv, Hashmovv, Jnsvva, Latif F, can be mentioned. (Джунусов М.С. 1993, № 3) .

Currently in practice the process of analyzing political dialogue is carried out by researcher. In this process, researcher carries out relational analysis through which some concepts such as relation, attitude and interaction are reviewed and studied. However, as we see, there is no appropriate approach for study of political approach.

Study of social and political and the communication analysis dates back to 90 years ago, this has changed into a process almost in 1985. Meanwhile, the philosophy of political dialogueue has been developed in various forms, "intersubjective", the "Communication", and "concepts", other than those that can be found earlier. The first step in the study of political dialogueue appears to be study of political and social analysis in Tajikistan. (Eg Articles Q Rasoulof, Mohammad F (Махмадов. Душанбе, 2010; 2011). In general, understanding the perspectives of the political dialogueue develops a lot of issues, including political dialogueue and societal relation. This means that, for political dialogueue in the modern world social issues are of high importance. However, this value only in the development of political dialogueue as a tool for conflict resolution and conflict begins, which among the people will be realized as a social value.

a. Political dialogueue: in general, all countries, of course, did not reach a consensus for not ending up to war, political dialogueue method is used. Fact, it may even be that the two countries while there have been at war, they still attend negotiating table to dialogue.

This process may be of different tools to be used. Political dialogueue may be used in international organizations, or regional level to achieve national or regional goals.

In general, political dialogueue may be used to remove ambiguity, or bring about a mutual interaction, according to the wishes of the parties, in the diplomatic, regional or international Area. In other words, the dialogueue, as a form of discursive engagement in the policy process, which is, in political dialogueue as a tool for conflict resolution, and it has considerable effect. (Махмадов. Душанбе, 2010; 2011.)

\section{b. Necessary conditions for a constructive dialogue:}

Dialogue, like any other human activity seeks specific results and purpose. Such, any action that Human being would do is a search on the purpose and the result. Also the results should not be separated and inconsistent, because, otherwise, this would be of no meaning. Hence, if the conversation as a research process is to be successful then, pre-conditions should be provided and this should proceed within certain parameters, especially in terms of negotiating a successful outcome. This process also means that to resort to the ultimate goal demands. 


\section{c. Tools, political dialogue:}

\section{(a)-an interior tool:}

1: good understanding on the subject: If the parties are prepared to deal with shared objectives and relative convergence in the talk, then they should have full grasp on the matter of discussion to achieve an appropriate agreement.

2: Language : The role of language in interaction of those who make dialogue is very important. proficiency on mutual language for conveying meaning, or the perception of the parties' demands, and to achieve a common objective seems to be among tools important of dialogue.

3: Use of Time: within a negotiation or dialogue in a meeting, one cannot answer immediately all the questions, by use of time are used and clarifying an appropriate response perhaps in another session, the time element can be used.

4: Courage and honesty: If a dialogue is featured by this component, the parties are more determined in achieving the goal, and achieving to the outcome will be more promising for both sides.

5: hear, and invite again: re-invite the parties, and the willingness to accept re-listen to the wishes of the parties can be another important tool of dialogue.

6: Ping-Pong table: talk of negotiations is like a Ping-Pong table. In any negotiation, maybe you take a score from opposite party or lose it, and if in conversation, you made a mistake, then apologize, and if one leaves the table, do not leave the table because it may set the stage or the resumption of negotiations.

7: Unpretentiousness: avoiding any selfishness, and top-to-down attitude assists in bringing the dialogue to an outcome. Dialogue should be coupled with the atmosphere of combined unpretentiousness, and hearing the other side demand.

8: Summarizing points, and avoiding the stressful points: in the process of achieving the outcome negotiator should be featured by summarizing and identifying and understanding strengths and be able to avoid stressful points and put forward a new agenda to approach negotiators to agreement (www.dreftekhari.)

\section{(b) External tool:}

1 - Change the military balance serves as a tool for creating change in the political dialogue (in case of war or peace, the military situation improvement, or power balance) to influence the dialogue.

2 - Change the political discourse as influence in the dialogue (change and impact in terms of improving dialogue).

3- Strengthening and membership in international relations (membership in organizations such as Shanghai. Islamic Conference. NAM ...)

4 - Build a culture within fundamental variables: fundamental variables of culture can be elements and internal capabilities of a culture which underlies international relations. Elements and components such as power of judgment, adaption, conflation, creativity and innovation are of most important of these parameters. Based on these parameters, social and civic groups are organized, and cultural international communication would be developed. (Terry McKinley, page 501) Therefore, if this culture development takes place, negotiators would be of strong support for negotiations.

\section{Political Dialogue (Politics of Dialogue) as a Form of Cultural Dialogue of Iran with Emphasis on Shanghai Cooperation Organization}

Within 1990s, the Islamic Republic of Iran brought some changes in its foreign policy, and foreign policy showed greater flexibility. To return to the former role as a regional power, Iran should show more attention to relations with its neighbors.

After the collapse of the Soviet Union, Iran sought to develop its relations with Central Asian countries, while previously there was no such possibility, when central leadership used to control communication of Soviet Union countries and the Ministry of Foreign Affairs. On the other hand, deliberated Nations from the USSR in gap of absence of the Soviet Union quickly sought to fill this void by countries like Iran. Yet, other powers which were present in the region, and especially, adjacent to their boundaries were organized in various aspects in this respect. In this region, coexistence has been existed for centuries with the promotion and dissemination of various religions. Following the collapse of the Soviet Union, social tensions in the region were created, which increases the risk of conditions such as war based on ethnic, national or religion background. 
Due to the vast area and more change to physical relationship with these countries, Iran is potentially at fairly high level of vulnerability in terms of ethnic conflicts. However, due to the relative stability in Iran, it doesn't cause deep concern in Iran, therefore, Central Asia, due to the proximity of cultural - historical interest to Iran is matter of attention of the Iran Foreign policy. However, unexpectedly due to the sanctions imposed by the West, Iran has many opportunities in Central Asia which is required by Iran, and the situation around the Caspian Sea is entirely obvious. Therefore, it can be seen that, most northern countries of Iran require gas, electricity, and especially the facilities necessary to meet the urban and population needs, as well as industry connections. In particular, supply provision through the Caspian Sea to the surrounding countries by ship comparing with the hard ground and sometimes far more expensive in the south, or from the land.

In addition, the presence of Iran helps in preserving the stability of conditions in the region, however, Iran seeks to foster the development of national movements, or weaken the Taliban, Salafism and excommunication which it has a lot of ground in this region, attempt to establish strong dialogue for relating with Central Asian countries, and strengthen political, economic and cultural bonds with these countries. Thus, there was some wrong concern that, there was the concern that if Iran develops the relationship with Central Asia, and Tajikistan Tehran encourages the spread of radical ideas in Central Asia. However, currently in recent years, especially in 2013 and 2014 as some events have happened in the region, such as the conflict in Syria and Iraq, by extremist group ISIL, backed by Saudi Arabia, actually provided regional countries with insight that role of leadership of Iran is rational enough and not only in politics and ideology, but also on their relationships, they seek to keep moderation with these countries, while maintaining mutual respect, and consideration.

After independence of Central Asia and the Caucasus region, senior officials of the Islamic Republic of Iran stated with confidence that their policy is expanding the foreign policy of not intervening of non-regional countries in Central Asian stability without interference by Iran as well. Accordingly, with regard to political interest and Iran national security, support for peace and stability is guaranteed in the region.

Tajikistan for the two countries - Iran and Russia - is of great importance from the point of view of ensuring peace and security.

The republics of the Soviet Union during the Cold War had some security problems with acute political and military issues. But in recent decades new norms of the security sources were addressed, including economic, social, cultural, and military criteria. Thus, factors such as technology, ideology, nationalism, increasing interdependence of nations in the context of globalization, convergence of ideas, international relations, problems of saving the environment, economic and political relations between North and South have been considered as factors of stability or disorder in international and regional security.

In these countries, besides attracting people with incapability in management, political power is unable to fulfill the demands and expectations of their people, and this itself lead to social tension, and internal threats in the Russian Federation which is the manifestation of the disorder. Conversely, the ability of the regime's political power, at the appropriate level is a factor in the consolidation of public safety. This ability, in today's society presents a method of political, cultural, technical, scientific, educational, and military instruments.

On the other hand, Central Asia is distrustful to Russia in terms of strategic security. Tajikistan, although in the period from 1993 to 1997, despite civil war has politically survived, yet, some negative effects are intangibly sensed in this country.

At that time we see that the Russian and Uzbekistan made support and cooperation in civil war in Tajikistan,, as long as F. Rahman came to power, this intervention continued. And Russia influence in Tajikistan and neighboring countries continued after signing a peace agreement in June 1997. Russia during the civil war in Tajikistan was present and participated. So that this country has been introduced as 201st peacekeeping Infantry Division. Here, they discuss policies to combat international terrorism, preventing radical religious development, in addition to the military action was needed. (Кулои, 1381:97.) As a result of the collapse of the Soviet Union and the subsequent disappearance of the bipolar world had sought, and unlike some of the analysis, the appearance of Central Asia and the Caucasus, as one of the most important strategic area, which has large reserves of oil and gas have contributed to the increasing importance of Iran. So that now the situation in Iran despite taking local conditions between the two main regions - the Persian Gulf, Central Asia and the Caucasus and turned into one of the strongest the geopolitical region. In fact, the new conditions prevailing in the southern areas of the Soviet Union, based on the fact that Iran acts as one of the major players in regional and international affairs. Therefore to achieve its goals, Iran actions and priorities are the following:

- Firstly, to promote and expand cooperation in political, economic, cultural and regional multilateral relation; 
- The second stage, the expansion of international communication, the construction of new railway construction machinery, railway network connecting Central Asia to the Persian Gulf, as well as active participation in peaceful resolution, from different ethnic, territorial, religious and internal conflict, which was welcomed by many of the leaders of the Central Asian countries (Махмуди М.Душанбе.2011.С.6).

Collaborative efforts between Iran and Russia through policy dialogue to maintain political stability and security in Central Asia and the Caucasus to expand mutual trust was managed by Iran. Meanwhile, Russia believes that Iran as a power a large area can guarantee stability in the region.

Within the conflict between Azerbaijan and Armenia, Iran as a mediator definitely acted and even managed to hold a series of political dialogue and to some extent alleviated the crisis in the region.

The civil war in Tajikistan between the Islamic and national forces Iran provided positive conditions and attempted to bring together the parties' positions, and active part in achieving a peace agreement between the United Tajik Opposition, and actively contributed in achieving peace agreement between the united opposition and the legitimate government of Tajikistan and at that time Iran showed to be as a positive mediator role. This active diplomacy on behalf of Iran, with the efforts and political dialogue can be seen as a result of activities in maintaining peace and stability in the region.

On the other hand, Iran has a shared border with the coastal countries such as Armenia, Azerbaijan, Turkmenistan and the Caspian Sea. Despite militias, regional problems, such as conflicts of Nagorno Karabakh , Georgia, Chechnya, Tajikistan is involved as a country near the Iranian geopolitical, political interest. Central Asian States in a direct and indirect manner for physical proximity can brings about conflict with Iran and if it continues, may pose a threat to Iran. Civilian and military conflicts are also present in other republics, the main reason for concern is Iran. The security situation in Afghanistan and Iran and the Persian Gulf war in 1993 and the turmoil existing areas of Karabakh began in 1993, had reached almost near the Iranian border, and were of the factors that could trigger concerns of Iran. Iran, however, in the last decade managed to expand and deepen its relations with Moscow, on the one hand, and the Central Asian states. Thus, consensus of Iran and Russia is the important point in security and stability in the region. (Like today also) at that time, along with Iran, Russia tends to avoid further European and American presence in Central Asia. Iran and Russia believed that any kind of instability in the region is considered as a threat to their national security ", and they want to establish stability in the region by any means in particular, through political dialogue, mediation. in past years, Russia and Iran, also created relationships, security and stability in Tajikistan. Numerous political dialogues, and the current state of the negotiations between Tajikistan and the United Tajik opposition, with the participation of Iran and Russia directly, by the same token, he held, was performed, which showed their common points, in the settlement of the crisis, is in Tajikistan. Russia, fully understand that Iran was a good experience, in conducting a dialogue with the Group of mediators, and at the same time, be able to use the positive influence for peace and stability in Tajikistan. So nicely the two countries realized the strategic goals, the interests of Iran and the Russian Federation; in political dialogue, for the sake of peace and stability in Tajikistan, in action.

\section{Shanghai Cooperation Organization}

(SCO) represents a practical and significant example of political dialogue within international modern context which occurred on the basis of international agreement. SCO is a symbol for the dialogue of cultures and civilizations, and sets the stage for the relationship between countries, with different historical biography and belief and shared or different cultural values ("Моисеев Л. (03.06.10) http://infoshos.ru/ru.) The current conditions can be encourages to desire for development, and expand contacts, and convergence, and is a condition to open window to the world. "Dialogue between cultures leads to deepen cultural development, which leads to mutual enrichment, reducing the cost, and on the other hand, the creation and strengthening of cultural experience, in other specific cultures influenced within global culture, ' (."( Кокшаров Н.В. № 3. 2003. Political dialogue on the cultures provides an alternative to avoid the monologue. In the history of international relations, man develops among cultures in spite of a certain point with the plan of interaction with another monologue as a necessary component. "dialogue and discussion, of the national action plan is the relationship between different cultures, different regions, cultures, and between cultural values. A significant image of the interaction and dialogue produces culture of East and West, North and South. In this collection of cultures, Guénon. r. writes:

"as long as there is traditional civilization in the West, there would be no reason for interaction between East and West. Tradition cause opposition in the west because they have these two types of consciousness, instead of two cultural thinking, and more or less of a particular geographic realities, and this causes the trouble will be "P Генон. Paris, 1927; рус. перев., 1999). East and West, rich with tradition, two cultures with their own way of life, and because of the potential conflict of power and more modernization, and it is not culture that sparks off 
the conflict. This is because their attitude toward material issues in culture is very different from each other, From the perspective of the West, the East has always been the symbol of indiscretion. And this is West that with its rapid development maintains East. "Tradition" and "history" preserve peace and tranquility to the inner world of human beings. And the West, the exact opposite, with this thinking, they consider the West as always looking for progress, and change the old to the new processes. But, the fact everything west has is derived from the old science efforts of the Middle East, which West usurped it all in its own name.

Political dialogue, as a form of cultural dialogue in SCO, acts on the fact that, according to the Organization's political culture, thought, unable to rally the different culture, indeed, and these cases. SCO, an example of political discourse, global, fully describe the type of content Dialogue, and its direction, which is the origin of the investment effect and, as the International Association, and the associated countries, with a single geopolitical space, is, Shanghai Cooperation Organization, to solve the problems of the human scale, and relationship with, one of the participants in the dialogue with the international community is based on the Organization, the only deep respect, understanding and acceptance of practices for members, a variety of life, such as their member countries, such as China's Communists, liberal Russia, traditional market, and are able to mutually beneficial cooperation, and the implementation of political, economic and cultural projects, large scale, and management. This decision is the birthplace under the title of "international strategic thinking" of Jiang land is formed, And always, with the independent foreign policy of peace. This important factor, for the future of the Organization, with the establishment of a young council, of SCO founded research centers. Institution-building complete SCO searched for creating a new model of dialogue, and regional cooperation. For example, right now, when there are disputes, created due to cultural differences and history, insurmountable occur between countries of the Organization, the organization can have the same cultural participation in Eurasia, and it is seen, therefore, that boosts the level of the conversation, and the relationship and prevent hostilities. In other words, at present, SCO is a reflection of, the proper approach to the biggest issues, with political dialogue, through its members-Russia and China, as part of these approaches, and political dialogue, as a kind of cultural dialogue in areas of significant economic, political, and cultural, in the structure and implementation.

Now, the Organization has the ability to stimulate and build a clear and effective political dialogue, in the development of relations, co-ordinated in the world, and the level of international relations. Based on comparative analysis of this definition, that political dialogue implementation is derived of the interaction of different cultures, hence, it seems that the Organization, in General, and at different levels pay attention to the dialogue between members of different organizations.

Within the framework of the laws of the Member States of the SCO, and between countries and projects are supported by UNESCO, (e.g., the protection of heritage, and Buddhist sites in Uzbekistan, World Heritage sites, identification of cultural heritage and China's 35 bases, including the Great Wall of China and Chinese works, such as Red Army, etc.). Therefore, the role and influence of the conversation is that, historically is derived from the East-West dialogue, and have effective influence on status quo, through the mechanism of the SCO cooperation with the Western world has been put into action. Therefore, through these interviews one can achieve the realization and popularization of sustainable peace and development of the idea.

Today, SCO, in practice undertakes a new concept for the operation, taking into account global changes, with the aim of changing it into one of the world's multipolar centers. This prestigious international organization, despite its position as the cultural structure, as a very strong cultural structure, which aims to provide solution to global problems, and preserving international interests, and common goals, along with the development of world cultures.

Also Iran in this approach seems that ideally want to benefit SCO, to find a way to avoid the problem of foreign security, avoiding a compromise forced by the demands of the Western countries, international action in preventing and reducing the sanctions, or eliminate the threat and pressure, from America. This is possible only if the organization gives some the assurance to Iran. Iran's geographical position, and the very positive economic opportunities within the country strengthen the percentage of chance to become a permanent member of the Organization. However, on the other hand, the conflict between Iran and America, reduces the chance, because none of the Member States do not intend to weaken their relation with the West for the sake of Iran's anti-Western policy (The policy dialogue $(5+1)$ nuclear Iran (2014) may increase this percentage). Therefore, you should say that, SCO, is an exclusively peaceful organization, on the other hand, and this has caused disagreement of Washington, because, they believe that, SCO is becoming increasingly an anti-American entity (Бахтиёр Миркасымов. (2006), стр. 87.) Because Iran does not belong to any regional defense organization, so the vulnerability of regional and international threat of Iran seems to be high. Iranian membership in the Organization considerable helps Iran power, due to the goal of reducing the volume of regional threats, and 
participation in regional cooperation in the economic and defensive national interests of the regions and national growth by permanent membership of Iran:

* Iran use of organization economic, commercial and transport capabilities.

* Strengthen the further dialogue with the West by organization in the international arena.

* Increased regional partners in trade and economic sectors, transportation, and global market.

* Selection of Iran in the organization serves as a kind of strengthening the role of impact and influence in the northern areas. The policy language, and in Farsi language is one of the positive points of cultural influence in the northern regions, particularly Tajikistan.

* For Iran, the organization is one of the ways to establish the relationship with the West, through which the organization can strengthen their position, etc. (М.Моради. 1386)

* Iran can serve as bridge connection between Central Asia and Europe, and can be used as goods and energy transit for Central Asia. This process is simple can serves as a means for strengthening Iran's interests by playing this role. (Х. Ахмадиян., 1386-87.)

Regardless of current directorship of Iran for Nam (2012_so far), during the past 30 years, the SCO is for the first time a set for joining to a regional and International Union. However, the arrival of the SCO includes consideration of such opportunities, and threats, which the organization can apply to Iran.

Iran is looking for original membership in the SCO; this politics is a kind of strategic interaction, and cooperation by Iran, to deal with the pressure of the West, and the United States, in particular, on the nuclear issue and human rights. For China and Russia, Iran is a tactical tool, is, therefore, in consideration of Iran's trade position, in the international system is discussed, and Iran, to Russia and China, become a chance and change the position, against the West, which is, for example, It is natural that the two countries, Russia and China prefer their interests with west to Iran's interests.

* The development of political and economic cooperation between the two countries (Iran and Tajikistan) with countries of China, Russia, and Central Asia, through establishing economic, political, and bilateral and multilateral defense cooperation with the West can assist in national interests of both countries.

* Russia and China tend to open the way to Persia, and Central Asia, so that, even force Iran, to put some of its abilities at their disposal.

* The great strategy of Russia and China at the global scene is based on Iran's resistance against the United States, particularly on the Iran nuclear issue, which is on the agenda of the Security Council, and they consider any progress on the issue of Iran's membership in the sco depends on solution of this problem.

On the other hand, Iran mustn't consider the membership as a strategic approach, because this organization is faced with limiting the principle:

a-The instability in Central Asia: this fact has caused distrust in the Organization.

b-issue of establishing coordination between the various mechanisms of cooperation, in Central Asia: including the joint plan for peace, NATO, the Commonwealth independent States, Guam and the Eurasia economic society.

c- Excessive differences, and a lack of symmetry between the members.

Practically, there is an American influence and hint in any international event while there are some international events in Central Asia, and thus, America may uses these events to win the game, and welcomes it with open arms. it would be wrong, to assume that, SCO is an organization derived from the cold war. This is a regional organization, it is impossible to imagine to develop it in this direction in coming years, and one of the reasons is geographic location (М. Саджадпур. 1985, стр. 33) And unequal opportunities for its members.

It should be noted that and the approach and relationships of Russia and China, and Central Asia are not the same.

China, without any pressure and threat, easily and quietly seeks to obtain for Central Asia market action, but Russia's action is a different method. Moscow has declared that the Central Asian geopolitical area is under its influence and, tends to keep countries in the region under its influence. therefore, to achieve this objective, it addresses international organizations, to strengthen, including his actions, such as SCO's. (www.tabadolnazar.com) China's is more interested in economic cooperation, but Russia tend to emphasize the importance of political and military organization, and defying against United States, and the North Atlantic Treaty, NATO, and as a result, it wants to prevent US influence. On the other hand, the Central Asian countries 
like Tajikistan seek to strengthen their independence and stability and ensure their economic development. These countries, in fact, need and interest further in economic cooperation than political and military rivalry. Therefore, the Central Asian States prefer the average political talk, and seek good relations, mutual beneficial economic cooperation with all countries in the world (www.irardiplomacy.ir) we should consider that Kazakhstan and Kyrgyzstan are heavily against Iran influence in their countries. This, the agent triggers for America against the membership of Iran to the SCO, they believe that this issue may bring about a crisis for the Organization, so, they deem their stability and its position at stake, they consider the membership of Iran to SCO depends on solving the problems between Iran and the West. it seems that the positive and active strategy of Iran in the near future would be able to find its true position within hierarchy of global structure. (Сайфзода. 1384, стр. 21) Naturally, it seems that Iran should think of use of the other players and mechanisms to deepen their level of national security, in addition to membership in the SCO (www.mardomsalari.com). Directorship of the movement of non-commitment, and political talks $(5+1)$ is a sample of these cases of Iran, using political dialogue with many countries, especially in Tajikistan and Central Asia, during the years of civil conflict, it played the role of interaction and eliminates hostility in the region. It seems that in the past few decades, either at the time of the power of the Taliban in Afghanistan, as well as the current (The war in Iraq and Syria. 2016.), this idea should be considered that inception of extremism and Takfiri thought and Talibanism can be a starting point to change within region. With the arrival of the Taliban in Afghanistan, and the rise of Takfiri Islam, drug trafficking and separation of security and stability, the Central Asia atmosphere has been affected, however, with the removal of Taliban power, development and sale of drugs still continues. In addition, practically with the development of Islamic extremism, drug trafficking, in the region of Central Asia, along with influence the Taliban doctrine, their effects are accelerated.( Джонсон Алисон, 1382, стр. 82)

The question is which way SCO should choose, and how it should evolve it, this is an important issue for the organization. In General, organization development depends on all members' requests and their own abilities. The organization may use the experience of the European Union, ASEAN, and other regional cooperation organizations. However, the Organization, taking into account the fact that there is special features in most case, it must choose its path of development due to difference in members. From other side, China is of highest population in the world and Russia is a vastest country, and on the other hand, in this series, there are small countries with small populations, which, in terms of cultural and religious points are different with each other. In addition, these countries are different in terms of the political and social system, economic development level.

So, with all of our previous analysis, we can understand the culture of communication, such as, the existence of a historical, political and functional shapes, which reflect the intrinsic quality of human mentality and identity, character, and the objective conditions of life. Emphasis of man on Ethics, as the biggest achievements of human culture is a way of life that reflects dialogue and communication. Of the functional forms, selecting communication and socialize, which is a unique quality within every human being, that this would cause the possibility of attracting, or repulsing in politics or political dialogue, by means of all the values of human culture, in the past, present, and future. Therefore, in line with this thinking, and for this discussion, in Central Asia, this is Iran that takes initiatives to improve the level of communication as significant step in relations in Central Asia, especially Iran and Tajikistan. To start this process was the visit of Emamali Rahman in Tehran, in July 1995, and the Grand inaugural of the Tajik Embassy in Tehran. Certain improvements, from Iran, in Central Asia, particularly in Tajikistan are selected due to the fact that the national interests of the two countries and the ideological goals of the revolutionary is a priority. Of course, the political dialogue in Tajikistan, which is completely devoid of any kind of emotional or ideological layers, and this relationship seemed pessimistic at that time, due to the civil war in Tajikistan, but it was done.

The dialogue between Tajikistan and Iran, and political organizations who participated in the negotiations between the Tajik Government and the opposition was done with the support of Iran, and Iran managed to set forth a good tackling and mediating by understanding of the circumstances of the parties, and observe the neutrality, and taking into account the territorial integrity of Tajikistan.

\section{Summary and Conclusions}

Political dialogue can be used as an influential military means for attaining to national objectives and approaching nations together. Iran with its decades of experience in the political dialogue between Central Asia and the Caucasus and Tajikistan, and offer a dialogue of civilizations at the international level, and nuclear and political talks between Iran and Europe (2014-2016) was a pioneer in this regard.

With regard to the current changes in the Middle East, and the war in Iraq, Syria and Palestine, the existence and strengthening of takfiri thinking, and the recent changes in the country's separatist ambition of Ukraine from the 
collection of Russian-speaking countries, in this circumstance, the political dialogue can reduce the conflicts in the region and results in promoting the relations between nations. The existence of two countries, Iran and Tajikistan with feature of Persian language, while Iran is featured by appropriate conditions and commercial communication channel, with the free sea, and Tajikistan, as a country with Iranian culture, and both countries are very close to each other, at the same time Tajikistan has relation with Russian-speaking countries, and is a permanent member of the SCO. Considering the positive changes with respect to nuclear talks of Iran and USA and five European countries, SCO can result in development and solution of problems and fostering relation of Iran with countries in the region and upgrade the interest of Both Iran and Tajikistan. This is an available potential for achieving the boost in political and economic dialogue to drive the region in its best manner to foster relation and dialogue and fostering and supplying common interest in the region.

\section{References}

Anbari, M., Bagheri, R., \& Davodi, H. (2013). Survey of Social factors Effective on discontinuation of innovation in rural areas (Case Study: Drip irrigation Technology in Lorestan). Journal of Science and today's world, 2(5), 451-464.

Beyer, P. Religion and Globalization. / Theory, Culture and Society Series. I Title, Series II. London 2000; Doran, Charles F. Globalization and Statecraft. SAISphere, Winter 2000; Fridman, Thomas L. The Lexus and the Olive Tree: Understanding Globalization. New York, Farrar, Straus and Giroux , 1999.

Davodi, H., \& Maghsoudi, T. (2011). Analysis of Potato Growers' Knowledge about Sustainable Agriculture in Shushtar Township.

Davodi, H., Maghsoudi, T., Fami, H. S., \& Kalantari, K. (2013). Evaluation of strategies for developing the agriculture technology in the science and technology parks of Iran from faculty member aspect. African Journal of Agricultural Research, 8(30), 4148-4156.

Maghsoudi, T., \& Davodi, H. (2011). Entrepreneurship Development Strategies in Agriculture Cooperatives in Iran. American-Eurasian J. Agric. \& Environ. Sci, 10(2), 283-289.

Maghsoudi, T., Davodi, H., \& Hekmat, M. (2013). Agricultural production cooperatives, entrepreneurship and education in Iran. African Journal of Business Management, 7(18), 1806.

Maghsoudi, T., Hekmat, M., \& Davodi, H. (2012). Supporting the entrepreneurship development in the agriculture production cooperatives. African Journal of Business Management, 6(10), 3639.

Rasoul Mousavi. According to the Tajik peace document, the Foreign Ministry publish Center, Tehran 1382

Terry MC Kinali. Measurement of human culture in the welfare contribution: the cultural indicators developed world culture report 1998.

айид Хусейн Сайфзода. Внешняя политика Ирана. Тегеран, Нашре Мизан, 1384

Бахтиёр Миркасымов. ШОС с точки зрения России. Перевод Маъсуме Зафарманд, Ежеквартальный журнал МИД ИРИ, №55, осень 1385 года (2006),

Генон Р. «Кризис современного мира» ("La crise du monde modem". Paris, 1927; рус. перев., 1999

Джунусов М. С. Культура межнационального общения. Белгород, 1982; Губагло А.В. Современные этноязычние процессы в СССР; М.: Наука, 1993; Хашимов Р.И. Таджикско-русское двуязычие. Душанбе: Дониш, 1986; Абдулатипов Р.Г. Время приходить к консенсусу //Конфликты и консенсус. 1993, №3.

Кокшаров, Н. В. (2003). Взаимодействие культур: диалог культур. "Credo new" теоретический журнал. № 3.

Мандана Моради. ШОС ва .вступление Ирана. Тегеранский Университет, зима 1386 г

Мандана Моради. ШОС ва .вступление Ирана. Тегеранский Университет, зима 1386r.

Махмадов А. Н. Процесс межнационального общения как социально политический феномен (на материалах Республики Таджикистан). Дис. на соск. уч. степени докт. полит. наук. Куляб, 1994.; Расулов С. Роль политическое общение в условиях трансформации общество (на материалах Таджикистана). Дис.на соиск.учен ст.кан.полит.наук. Душанбе, 2010; Махмадов С. Диалог как механизм разрешения социально-политического конфликта. Дис.на соиск.учен ст.кан.полит.наук. Душанбе, 2011.

Моисеев Л. ШОС перерастает региональные рамки (03.06.10) [Электронный ресурс] / Л. 
Моисеев/ЦЦентральный Интернет портал ИнфоШОС-Режим доступа: http://infoshos.ru/ru/?idn=6050, свободный - Загл. с экрана.

Мохаммад Хосейн Раджаби. Шиитские улемы и диалог между цивилизациями и религиями// Фирузе// Иран, 3 мая 2002.; Сейеда Садега Хакиката. Политическая мысль в исламе. - Тегеран, 1991.

Мухаммад Козим Саджадпур. Текст выступления на тему: Внешняя политика С(ЩА и ШОС; Анализ заявлений и последствия Манучехр Муроди, Отчет 14 международног семинара Центральная Азия и Кавказ, Ежеквартальный журнал: Центральная Азия и Кавказ, № 55, осень 1985.

Сажина В.И. Диалог цивилизаций: Россия и Иран //Иран: диалог цивилизаций. М., 2002; Мамедова Н.М. Политико-экономический аспект диалога цивилизаций (того же сборника); Дружиловский С.Б. Мировое сообщество и новая внешнеполитическая концепция Ирана” (названного сборника); Каменова М.С. Ирано-индийский языковой диалог (Там же); Амири М. Теория столкновения цивилизаций: Хантингтон и его критики. Тегеран, 2002.

Хамза Ахмадиян. Интересы и вред членства Ирана в ШОС. Тегеранский Университет, 1386-87 гr.

Шахрамния С. Джахони шудан ва демокраси дар Ирон. Техран: «Нигохе муосир», 2007 (1385).

\section{Copyrights}

Copyright for this article is retained by the author(s), with first publication rights granted to the journal.

This is an open-access article distributed under the terms and conditions of the Creative Commons Attribution license (http://creativecommons.org/licenses/by/4.0/). 